\title{
Effect of nicotine on rectal mucus and mucosal eicosanoids
}

F J Zijlstra, E D Srivastava, M Rhodes, A P M van Dijk, F Fogg, H J Samson, M Copeman, M A H Russell, C Feyerabend, G T Williams, R D Pullan, G A O Thomas, M Van Blankenstein, J H P Wilson, A Allen, J Rhodes

\begin{abstract}
Because ulcerative colitis is largely a disease of non-smokers and nicotine may have a beneficial effect on the disease, the effect of nicotine on rectal mucosa in rabbits was examined. Nicotine was given subcutaneously by an Alzet mini-pump in doses of $0.5,1.25$, and $2 \mathrm{mg} / \mathrm{kg} /$ day for 14 days to three groups of eight animals and compared with eight controls. Mean (SD) serum nicotine concentrations $(\mathrm{ng} / \mathrm{ml})$ were $3.5(1.1), 8.8(2.3)$, and 16.2 $(5 \cdot 2)$ respectively in the treated groups. The thickness of adherent mucus on rectal mucosa in controls (median $36 \mu \mathrm{m}$ ) was significantly reduced by low dose $(22 \mu \mathrm{m}, \mathrm{p}=0.0011)$, and increased by high dose nicotine $(48 \mu \mathrm{m}$, $\mathbf{p}=\mathbf{0 . 0 3 5}$ ). Incorporation of radioactive glucosamine into papain resistant glycoconjugates was unchanged, indicating that mucin synthesis was unaltered. Prostaglandins (PG) were reduced, in some cases significantly (6-keto $\mathbf{P G F}_{1 \alpha}, \mathbf{P G F}_{2 \alpha}$, and hydroxy-eicosatetraenoic acid), by nicotine, which showed an inverse dose dependence - with greatest inhibition in relation to the lowest dose. Nicotine, and possibly smoking, may affect colitis by an action on mucosal eicosanoids and on adherent surface mucus secretion in the rectum and large bowel.

(Gut 1994; 35: 247-251)
\end{abstract}

Ulcerative colitis is predominantly a disease of current non-smokers, ${ }^{1}$ many of whom are exsmokers who develop their colitis after stopping smoking. ${ }^{2}$ Anecdotal reports suggest an improvement in colitis when some patients start smoking again..$^{3-5}$ Nicotine may be the active agent responsible for this improvement and a pilot study of transdermal nicotine administration in patients with active disease seemed to show benefit. ${ }^{6}$

Mucus in the colon forms a continuous adherent layer on the epithelium, acting as a barrier between the mucosal epithelial cells and the luminal contents. Since ulcerative colitis is a mucosal disease, damage by luminal contents may play a role. Factors responsible for maintaining the mucus barrier may therefore be pertinent to the pathogenesis of colitis. These include synthesis and secretion of mucin, ${ }^{7}$ thickness of the adherent surface layer, ${ }^{89}$ and activity of luminal proteases which are responsible for digestion of the mucus gel barrier. ${ }^{10}$ Mucosal eicosanoids may also be relevant since, by analogy with the stomach, they probably stimulate mucin synthesis and secretion. ${ }^{11} 12$

Elucidation of the mechanisms involved in the relationship between smoking and colitis may lead to therapeutic advances. We have therefore examined the effect of nicotine on colonic mucus and mucosal eicosanoids in an animal model.

\section{Methods}

ANIMALS

The rabbit model was chosen because the eicosanoid profile for colonic mucosa is similar to that in man, and preliminary studies in mice failed to produce adequate plasma nicotine concentrations. Thirty two male New Zealand white rabbits weighing between 2 and $2.5 \mathrm{~kg}$ were allocated randomly to four groups - a control group and three treatment groups with eight rats in each group. Nicotine hydrogen tartrate (BDH Ltd, Poole, England) was given over 14 days by subcutaneous infusion in doses equivalent to 0.5 , 1.25 , and $2 \mathrm{mg} / \mathrm{kg} /$ day of nicotine base, dissolved in saline, in the three treatment groups and saline was given to controls. An Alzet osmotic mini-pump (model 2ML2) with an infusion rate of $5 \mu \mathrm{l} / \mathrm{h}$ was implanted under halothane anaesthesia and each animal was housed separately with food and water supplied freely. One $\mathrm{ml}$ of blood was taken from the ear vein initially and on days 6 and 14 for measurement of plasma nicotine. ${ }^{13}$ Each rabbit was weighed initially and at 14 days, when they were killed and the rectum, colon, and caecum removed. Measurements were performed without knowledge of the group to which animals belonged.

\section{MEASUREMENT OF MUCUS THICKNESS}

The visible layer of adherent mucus in the rectum was measured immediately using an inverted microscope on mucosal sections $1.6 \mathrm{~mm}$ in thickness as previously reported. ${ }^{1+}$ The rectum was chosen for these measurements because it was the only site in the large bowel where flat mucosa could be gently dissected from the underlying tissue without distortion. In the remainder of the colon, there were large folds which made measurement unsatisfactory. Measurements from each piece of resected mucosa were made on three sections using an eyepiece graticule, and a minimum of 10 readings were taken on each section. Each animal was characterised by the mean of the readings made.

MEASUREMENT OF THE MUCIN SYNTHESIS RATE Tissue samples from the rectum were suspended in a standard culture medium which included D $\left[6^{3} \mathrm{H}\right]$-glucosamine. The methodology used 
was identical to that previously described for gall bladder mucosa. ${ }^{15}$ Mucosal explants were cultured for 24 hours at $37^{\circ} \mathrm{C}$ in an atmosphere of $95 \% \mathrm{O}_{2}$ and $5 \% \mathrm{CO}_{2}$ in a standard tissue culture incubator. Tissues underwent papain digestion for 72 hours to isolate carbohydrate-containing segments of the mucin, followed by exhaustive dialysis to remove low molecular weight material before measurement of $3 \mathrm{H}$-glucosamine incorporation. ${ }^{16}$ This procedure has previously been shown to isolate papain resistant radioactive glycoconjugates, a very large proportion of which is mucin, free from other glycoconjugates and without significant loss of mucin carbohydrate. ${ }^{1516}$ Radioactivity incorporated into mucin glycoconjugate was expressed as $\mathrm{dpm} \times 10^{3}{ }^{3} \mathrm{H}$-glucosamine incorporated per gram wet weight of mucosa.

Preliminary studies were done to justify the use of wet weights of mucosa as representative of epithelial tissue mass. Twelve samples of fresh rectal mucosa, which varied in size between 2 and $42 \mathrm{mg}$, were blotted, weighed, and dried overnight at $40^{\circ} \mathrm{C}$. They were then reweighed, homogenised, and further measurements made of both the protein ${ }^{18}$ and DNA $^{19}$ content. The respective correlation coefficients relating wet weight of tissue to dry weight, protein, and DNA contents were $0.79,0.95$, and 0.98 .

\section{MEASUREMENT OF EICOSANOIDS}

Tissue samples from the rectum and caecum ( 100 to $200 \mathrm{mg}$ wet weight) were stored at $-70^{\circ} \mathrm{C}$ for subsequent analysis of eicosanoids. On analysis, each sample was minced and homogenised in $1 \mathrm{ml}$ of Krebs-Henseleit buffer $\mathrm{pH} 7 \cdot 4$ by means of an Ultra-Turrax homogeniser (Polytron, Kinematica, Switzerland) for 20 seconds on melting ice. Total protein content was determined by a micro-scale method using an ELISA reader at $600 \mathrm{~nm}$ (Instruchemie, Hilversum, The Netherlands). Each tissue sample was incubated with $0.125 \mu \mathrm{Ci}$ [1-14 c - arachidonic acid (55 $\mu \mathrm{Ci} / \mu \mathrm{mol}$, Amersham, UK) together with $2 \mu \mathrm{M}$ calcium ionophore A23187 (Sigma) at $37^{\circ} \mathrm{C}$ for 15 minutes. Then ${ }^{3} \mathrm{H}$ labelled compounds of prostaglandins 6-keto $\mathrm{PGF}_{1 \alpha}, \mathrm{PGF}_{2 \alpha}$, and $\mathrm{PGE}_{2}$, thromboxane $\mathrm{B}_{2}$, hydroxy-5, 8, 10heptadecatreinoic acid (HHT), and 15-hydroxy eicosatetraenoic acid (15HETE) (Amersham, UK) were added as chromatographic standards and for the determination of the recovery. Samples were centrifuged for two minutes at $1600 \mathrm{~g}$ at $4^{\circ} \mathrm{C}$. The supernatant was applied to a Sep Pak $\mathrm{C}_{18}$ cartridge (Waters Ass, USA), diluted with methanol, and dried with a Savant Speed Vac concentrator. The pellet was dissolved in $250 \mu \mathrm{l}$ of methanol and filtered through an Anotop $0.2 \mu \mathrm{m}$ filter into an high performance liquid chromatography (HPLC) polypropylene microvial. Altogether $100 \mu l$ were injected onto two combined Nucleosil $5 \mathrm{C}_{18}$ HPLC columns $(3 \times 20 \mathrm{~mm}$, Chrompack, The Netherlands). HPLC was performed with a Hewlett-Packard 1084B liquid chromatograph with dual pumping system. Radioactivity was measured on-line with a Berthold LB506C monitor. The solvent system contained a gradient of $0 \cdot 12 \%$ tri-fluoroacetic acid and $0 \cdot 2 \%$ triethylamine in water ( $\mathrm{pH} \mathrm{3.0)}$ and acetonitril (Lichrosolv, Merck, Germany). The flow rate was $0.5 \mathrm{ml} / \mathrm{min}$ at $37^{\circ} \mathrm{C}$. Picofluor (Packard Canberra, USA) was used as a premixed scintillator at a flow rate of $2.25 \mathrm{ml} / \mathrm{min} .^{20-22}$

\section{FAECAL PROTEINASE ACTIVITY}

Faecal samples from the rectum and caecum were stored at $-70^{\circ} \mathrm{C}$ before processing. Samples were thawed to room temperature, suspended in $67 \mathrm{mmol} / \mathrm{l}$ sodium phosphate buffer, $\mathrm{pH} 7 \cdot 5$ containing $50 \mathrm{mmol} / \mathrm{l}$ sodium chloride, and centrifuged at $18000 \mathrm{~g}$ for 45 minutes at $4^{\circ} \mathrm{C}$. The supernatant was retained as a faecal extract. Proteolytic activity was measured by assay of new N-terminals formed on hydrolysis of peptide bonds. ${ }^{10}$ All samples were compared with zero incubation time controls. Proteolytic activity was expressed as mmol-N-terminals/ $\mathrm{min} / \mathrm{g}$ faeces.

\section{HISTOLOGY}

Tissue samples from the caecum and rectum were fixed in buffered formalin. Paraffin embedded sections $(5 \mu)$ were stained by haematoxylin and eosin, Alcian blue (pH 2.5)-periodic acid Schiff (PAS), and the high iron diamine (HID)alcian blue techniques. ${ }^{23}$ The latter two methods allow identification of neutral mucus glycoproteins (PAS posivite), non-sulphated sialomucins (Alcian blue positive), and sulphated sialomucins (HID positive). All samples were assessed histologically for morphological changes, inflammation, and alterations in mucus glycoprotein histochemistry, without knowledge of the treatment group.

\section{STATISTICS}

Each outcome measurement was compared between the four groups using the KruskalWallis non-parametric one-way analysis of variance; when this was significant, differences from the control group were assessed by MannWhitney $U$ tests. The change in serum nicotine concentrations from days 6 to 14 was assessed by the paired $t$ test.

\section{Results}

The mean (SD) concentrations of serum nicotine (ng/ml) from two measurements on days 6 and 14 were $0 \cdot 4(0 \cdot 2) ; 3 \cdot 5(1 \cdot 1) ; 8 \cdot 8(2 \cdot 3)$; and $16 \cdot 2(5 \cdot 2)$ in the control and three nicotine groups respectively (Table I). Compared with day 6 , values on day 14 had fallen by between 12 and $36 \%$, and the difference reached significance in the medium dose nicotine group $(p=0.026,95 \%$ confidence interval (CI) $0 \cdot 5,7 \cdot 02)$. When animals were killed, an unexpected observation on opening the colon was that those given nicotine had softer stools than controls, and the change was most striking in the high dose group.

The thickness of the adherent mucus in the rectum differed highly significantly between the four groups (Kruskal-Wallis, $p<0.001$ ): it was reduced $(p=0.0011)$ with low dose and increased $(p=0.035)$ with high dose nicotine (Table II). 
TABLE I Plasma nicotine concentration (mean (SD), $\mathrm{ng} / \mathrm{ml}$ ) in control rabbits and three nicotine treatment groups given $0.5,1.25$, and $2 \mathrm{mg} / \mathrm{kg} /$ day for 14 days with measurements on days 6 and 14. Each group contained eight rabbits

\begin{tabular}{lccc}
\hline Group & Day 6 & Day 14 & $\begin{array}{l}\text { Mean }(S D) \text { of } \\
\text { days } 6+14\end{array}$ \\
\hline Control & $0 \cdot 3(0 \cdot 20)$ & $0 \cdot 4(0 \cdot 30)$ & $0 \cdot 4(0 \cdot 20)$ \\
Low dose & $4 \cdot 0(1 \cdot 2)$ & $3 \cdot 0(1 \cdot 4)$ & $3 \cdot 5(1 \cdot 1)$ \\
Medium dose & $10 \cdot 8(3 \cdot 2)$ & $6 \cdot 9(2 \cdot 7)$ & $8 \cdot 8(2 \cdot 3)$ \\
High dose & $17 \cdot 3(5 \cdot 3)$ & $15 \cdot 2(6 \cdot 1)$ & $16 \cdot 2(5 \cdot 2)$ \\
\hline
\end{tabular}

tine (Table III, Fig 3). Values for caecal synthesis of eicosanoids 6-keto $\mathrm{PGF}_{1 \alpha}, \mathrm{PGF}_{2 \alpha}, \mathrm{PGE}_{2}$, $\mathrm{PGD}_{2}, \mathrm{TXB}_{2}, \mathrm{HHT}, 12 \mathrm{HETE}$, and 15HETE showed no significant difference between controls and treated animals.

Faecal proteinase activity was very low, between 7 and $50 \mu \mathrm{mol} \mathrm{N}$ terminals $/ \mathrm{min} / \mathrm{g}$ dry weight for the different rectal and caecal samples; these values were at the limits of

TABLE II Thickness of the visible adherent mucus on rectal mucosa (median (range)) with rates of papain resistant

glycoconjugate $(P R G)$ synthesis in control rabbits and three treatment groups given $0 \cdot 5,1 \cdot 25$, and $2 \mathrm{mg} / \mathrm{kg} /$ day of nicotine for 14 days. Mean synthesis rates are given as $D\left[6^{-3} \mathrm{H}\right]$-glucosamine $d p m \times 10^{3} / \mathrm{g}$ wet weight. Each group contained 8 rabbits.

Kruskal-Wallis tests compare the four groups

\begin{tabular}{|c|c|c|c|c|c|c|}
\hline \multirow[b]{2}{*}{ Rectal mucosa } & \multirow[b]{2}{*}{ Control } & \multicolumn{3}{|l|}{ Nicotine treatment } & \multicolumn{2}{|c|}{ Kruskal-Wallis } \\
\hline & & Low dose & Medium dose & High dose & $X^{2}{ }_{3}$ & $p$ \\
\hline Mucus thickness $(\mu \mathrm{m})$ & $36 \cdot 0(28 \cdot 8-43 \cdot 2)$ & $21 \cdot 6(19 \cdot 2-28 \cdot 8)^{\star \star}$ & $26 \cdot 4(19 \cdot 2-40 \cdot 8)$ & $48 \cdot 0(31 \cdot 2-52 \cdot 8)^{\star}$ & $19 \cdot 59$ & $<0.001$ \\
\hline $\begin{array}{l}\text { Synthesis of PRG } \\
\left(\mathrm{dpm} \times 10^{3} / \mathrm{g} \text { wet wt) }\right.\end{array}$ & $106 \cdot 2(94 \cdot 2-136 \cdot 6)$ & $108 \cdot 0(65 \cdot 9-131 \cdot 7)$ & $104 \cdot 9(43 \cdot 6-139 \cdot 9)$ & $92 \cdot 3(46 \cdot 2-141 \cdot 9)$ & 0.91 & $0 \cdot 82$ \\
\hline
\end{tabular}

Significant differences from the control group are identified: ${ }^{\star} \mathrm{p}<0.05,{ }^{\star \star} \mathrm{p}<0.01$.

There was a steady progress of mucus thickness from low dose to high dose, with no overlap between the values recorded for these extreme doses (Fig $1 ; \mathrm{p}<0.0002$ ). There was a significant correlation between mean serum nicotine values in each animal given nicotine and the corresponding thickness of rectal mucus, $r=0.71$, $\mathrm{p}<0.001$ (Fig 2). No significant change was found in the rate of synthesis of papain resistant glycoconjugates by rectal biopsy specimens in tissue culture (Table II).

Synthesis of several rectal eicosanoids showed inhibition which was statistically significant for 6-keto $\mathrm{PGF}_{1 \alpha}, \mathrm{PGF}_{2 \alpha}$, and 15HETE. There was again an inverse dose dependence with the greatest inhibition with the lowest dose of nico-

Figure 1: Thickness of adherent mucus on rectal mucosa in four groups of eight rabbits - control rabbits and three treatment groups given subcutaneous nicotine infusion in doses of 0.5 infusion in doses of $0 \cdot 5$,
$1 \cdot 25$, and $2 \mathrm{mg} / \mathrm{kg} /$ day respectively for 14 days. Each animal is represented by a single mean value of readings in that animal.

Figure 2: Correlation between mean serum nicotine values $(\mathrm{ng} / \mathrm{ml})$ on days 6 and 14 with the rectal mucus thickness $(\mu \mathrm{m})$ in 24 rabbits divided into three groups of eight and given doses of 0.5 , $1 \cdot 25$, and $2 \mathrm{mg} / \mathrm{kg} /$ day of nicotine respectively for 14 days $(r=0.71, p<0.001)$.
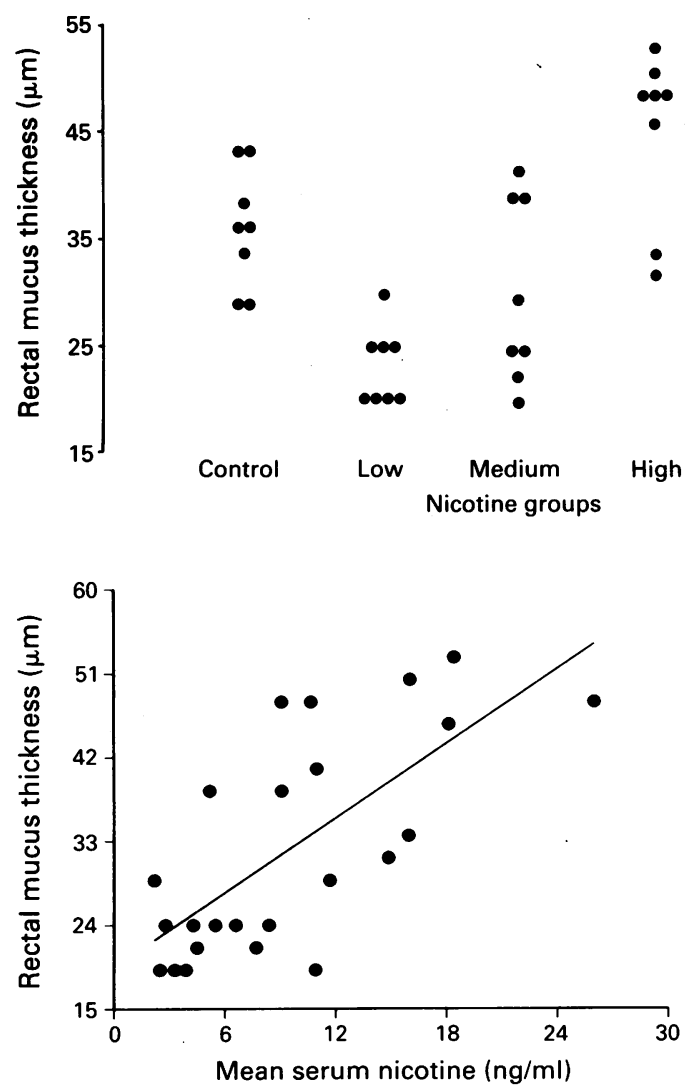

sensitivity of the assay. Nicotine had no significant effect on the values.

No histological changes were detected in any of the treatment groups. In particular, nicotine administration was not accompanied by mucosal inflammation, changes in the morphology of the large intestinal epithelial cells, or changes in histochemical reactions of mucus glycoproteins in goblet cells.

\section{Discussion}

Subcutaneous nicotine changed the thickness of adherent rectal mucus with an inverse dose relationship - greatest inhibition was observed with the lowest dose. Rectal eicosanoids were reduced in each of the treatment groups and in some instances (6-keto $\mathrm{PGF}_{1 \alpha}, \mathrm{PGF}_{2 \alpha}$, 15HETE) also showed an inverse dose relationship. In contrast caecal eicosanoids showed no significant change and it was not technically possible to measure mucus thickness in the caecum. These changes in the rectum occurred in the absence of any morphological or histochemical change.

Although the groups were relatively small, several of the observed changes were significantly different from control values and all measurements were carried out without knowledge of the treatment group. The serum nicotine concentrations were in the lower end of the $5-60 \mathrm{ng} / \mathrm{ml}$ range typically found in smokers ${ }^{24}$; the average in the high dose group being about half the average concentration in smokers. The standard methods used to measure mucus thickness ${ }^{14}$ and tissue eicosanoids ${ }^{20-22}$ are well validated and known to give reproducible results.

Incorporation of radioactive glucosamine into papain resistant glycoconjugates was not changed in any of the nicotine groups. Previous studies have shown that a large proportion of this papain resistant glycoconjugate fraction is mucin ${ }^{15}{ }^{16}$ and therefore it is reasonable to assume that no substantial changes in mucin biosynthesis occurred.

Changes in thickness of the adherent layer of mucus in the rectum after nicotine administration could theoretically be caused by differences 
TABLE III Concentrations of rectal eicosanoids (median (range)) in controls and three nicotine treatment groups given $0 \cdot 5,1 \cdot 25$, and $2 \mathrm{mg} / \mathrm{kg} /$ day for 14 days. Prostaglandins $(P G)$, thromboxane (Tx), hydroxy-5, 8, 10-heptadecatrienoic acid (HHT) and 15-hydroxyeicosatetraenoic acid (HETE) are given. Each group contained eight rabbits. Kruskal-Wallis tests compare the four groups

\begin{tabular}{|c|c|c|c|c|c|c|}
\hline \multirow{2}{*}{$\begin{array}{l}\text { Eicosanoids } \\
(d p m / m g \text { wet wt })\end{array}$} & \multirow[b]{2}{*}{ Control } & \multicolumn{3}{|l|}{ Nicotine treatment } & \multicolumn{2}{|c|}{ Kruskal-Wallis } \\
\hline & & Low dose & Medium dose & High dose & $X^{2}{ }_{3}$ & $p$ \\
\hline $\begin{array}{l}\text { 6-keto PGF } \\
\text { PGF }_{2 \alpha} \\
\text { PGE }_{2} \\
\text { PGD }_{2} \\
\text { TxB }_{2} \\
\text { HHT } \\
15 \text { HETE } \\
12 \text { HETE }\end{array}$ & $\begin{array}{c}75 \cdot 2(15 \cdot 4-120 \cdot 7) \\
11 \cdot 0(1 \cdot 9-39 \cdot 0) \\
3 \cdot 9(0 \cdot 6-17 \cdot 7) \\
0 \cdot 7(0-2 \cdot 1) \\
0 \cdot 2(0-0 \cdot 9) \\
26 \cdot 1(7 \cdot 5-34 \cdot 2) \\
19 \cdot 9(4 \cdot 2-99 \cdot 3) \\
1 \cdot 1(0-7 \cdot 6)\end{array}$ & $\begin{array}{l}4 \cdot 5(0 \cdot 8-38 \cdot 4)^{\star \star} \\
2 \cdot 3(1 \cdot 1-5 \cdot 0)^{\star} \\
1 \cdot 8(0-5 \cdot 2) \\
0 \cdot 3(0-1 \cdot 2) \\
0 \cdot 2(0-0 \cdot 8) \\
8 \cdot 2(1 \cdot 9-17 \cdot 0) \\
0 \cdot 7(0-7 \cdot 2)^{\star \star} \\
0 \cdot 0(0-1 \cdot 7)\end{array}$ & $\begin{array}{c}16 \cdot 9(3 \cdot 4-53 \cdot 8)^{\star \star} \\
3 \cdot 6(0 \cdot 9-16 \cdot 0)^{\star} \\
2 \cdot 0(0-6 \cdot 1) \\
0 \cdot 3(0-3 \cdot 1) \\
0 \cdot 0(0-0 \cdot 5) \\
15 \cdot 9(5 \cdot 4-23 \cdot 8) \\
0.0(0-9 \cdot 2)^{\star \star} \\
0.4(0-1 \cdot 1)\end{array}$ & $\begin{array}{c}36 \cdot 4(5 \cdot 3-93 \cdot 6) \\
3 \cdot 9(0 \cdot 5-23 \cdot 2) \\
2 \cdot 4(0-8 \cdot 2) \\
0 \cdot 1(0-3 \cdot 7) \\
0 \cdot 1(0-2 \cdot 4) \\
10 \cdot 4(2 \cdot 1-54 \cdot 1) \\
5 \cdot 1(0-15 \cdot 6)^{\star} \\
0 \cdot 0(0-0 \cdot 6)\end{array}$ & $\begin{array}{r}17 \cdot 03 \\
8 \cdot 66 \\
2 \cdot 05 \\
1 \cdot 68 \\
0 \cdot 81 \\
7 \cdot 75 \\
17 \cdot 64 \\
5 \cdot 18\end{array}$ & $\begin{array}{c}<0.001 \\
0.035 \\
0.56 \\
0.64 \\
0.85 \\
0.052 \\
<0.001 \\
0.16\end{array}$ \\
\hline
\end{tabular}

Significant differences from the control group are identified: ${ }^{\star} \mathrm{p}<0 \cdot 05,{ }^{\star} \mathrm{p}<0.01$.

in mucus synthesis or secretion rates, or faecal protease activity responsible for digestion of mucus. ${ }^{7-10}$ Because the results in relation to dose of nicotine we found were not initially hypothesised, it remains possible that they have arisen by chance. However, the consistency of a biphasic response for both eicosanoids and mucus makes this unlikely. The mechanisms by which low doses of nicotine are associated with reduced prostaglandin synthesis and nicotine with reversal at higher doses remain to be determined. While rates of glycoconjugate and therefore mucin biosynthesis seemed to remain unchanged, it does not follow that rates of mucus secretion were also constant. It was not possible to measure changes in the size of the intracellular preformed mucus pool which would indicate if rates of secretion were different from those of biosynthesis. Levels of faecal proteinase activity were uniformly low and would not explain the observed changes in thickness. Glycoconjugate synthesis was, of course, measured in vitro rather than in vivo using explants cultured for 24 hours: any nicotine present would probably dilute in the culture medium and one cannot entirely exclude a nicotine effect on synthesis rates. It is possible that the softer stools in those given nicotine, which were almost a slurry with high dose nicotine, could account for increased mucus thickness by reduced mechanical shear but this would not explain the reduced thickness with low dose nicotine. Further measurements with higher doses of nicotine giving serum values similar to those observed in smokers of 20 cigarettes a day or so would be of particular controls and those treated with subcutaneous nicotine infusion $0 \cdot 5,1 \cdot 25$, and 2 $\mathrm{mg} / \mathrm{kg} /$ day for 14 days.

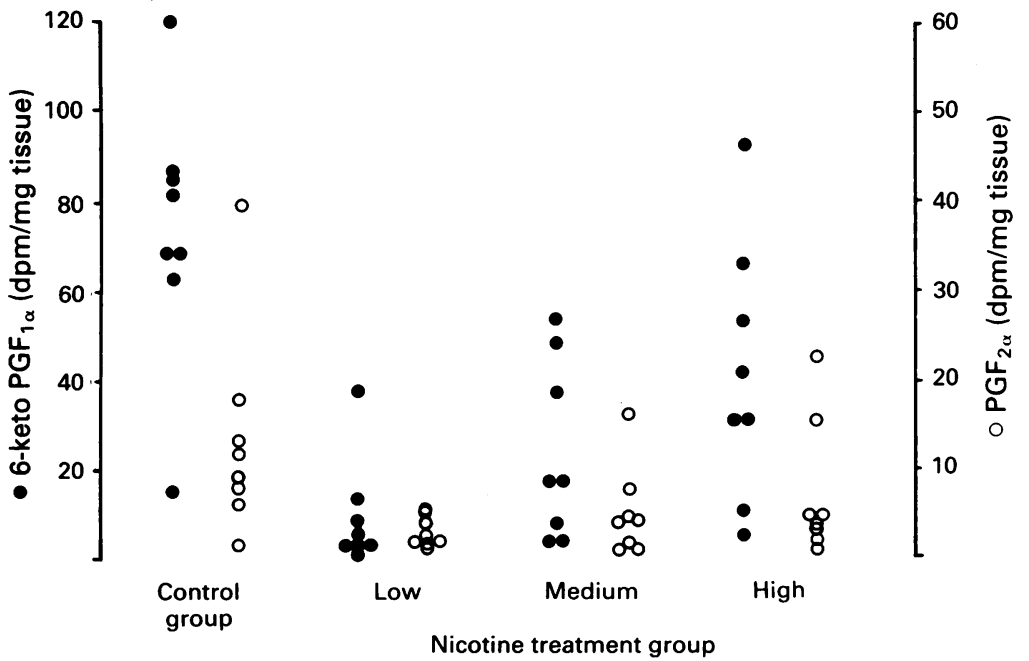

interest in clarifying this finding. Comparable measurements have not been made previously. Although Cope et $a l^{25}$ showed that mucosal biopsy specimens taken at colonoscopy from patients with ulcerative colitis who do not smoke have reduced mucus production compared with tissue from non-smoking controls, but colitis patients who smoke have similar rates of production to controls. Recent measurements of faecal proteinase in man have identified values in normal control subjects and patients with ulcerative colitis, who have activities over three times those of control. ${ }^{26}{ }^{27} \mathrm{We}$ are not aware of previous proteinase values in herbivores, like the rabbit, but suspect that the almost total absence of proteinase may be related to the diet or anatomical features in rabbits, which have a large caecum in which carbohydrate is fermented and this may account for the observed low faecal proteolytic activity compared with man.

The uniform reduction in rectal eicosanoids, some of which were reduced with an inverse dose relationship, is difficult to explain. Similar changes were not observed in the caecum but data suggesting lower concentrations of eicosanoids have been obtained in man from rectal biopsy specimens in which healthy smokers were compared with non-smokers. ${ }^{28}$ Parallel observations in the stomach have also shown reduced values in smokers. ${ }^{29}$ Broncho-alveolar lavage fluids of female smokers and non-smokers have also shown a positive correlation between $\mathrm{PGF}_{2 \alpha}$ and $\mathrm{TxB}_{2}$ levels and the number of 'pack years'; in parallel with this the number of macrophages increased and gave a negative correlation to prostaglandin levels. ${ }^{30}$

In patients with active ulcerative colitis, sulphated mucus glycoproteins are diminished ${ }^{31}$ and specific changes of mucus subfractions have been observed even in early phases of the disease. ${ }^{32}$ The bacterial enzymes which are relevant to mucus degradation include glycosidases, sulphatases, sialidases, acetyl esterases, and proteinases. ${ }^{133}$ Sulphatases have been shown in faeces from both normal subjects and patients with colitis. ${ }^{34}$ Sialidases are also commonly present but probably have to act in synergy with the sialic acid 0 -acetylesterases, which have also been found in human faeces. ${ }^{26}$ No convincing difference has been found between concentrations of the carbohydrate degrading enzymes in patients compared with controls, but increased concentrations of faecal proteinases have been reported in colitis. ${ }^{2627}$

The inter-relationship between mucosal eico- 
sanoid production and mucus synthesis has been explored in the stomach, where increases in eicosanoid values are associated with increased mucus thickness and synthesis. ${ }^{1435}$ Such eicosanoid-induced increases in the thickness of the mucus barrier may play a role in protection of the gastric mucosa, particularly against pepsin damage. ${ }^{36}$ Similar associations may apply in the rectum and may be relevant to the pathogenesis of ulcerative colitis. Increased endogenous secretion of mucosal prostaglandins may stimulate both synthesis and secretion of mucin, which may in turn enhance the surface barrier on the colonic mucosa. This is supported by the reduction in mucus thickness and prostenoid levels with the low dose of nicotine and the inverse dose relationship at higher nicotine levels. Observations on eicosanoids in colitis are somewhat disappointing and simply show high levels during phases of activity that return to normal with clinical remission. ${ }^{37}$ It is difficult to attribute a role to agents which appear as indicators of acute inflammation but also have the potential of protecting mucosa from damage. Intraluminal $\mathrm{PGE}_{2}$ has been shown to protect against colitis ${ }^{38}$ in a rat model where colitis was induced by alcohol.

In recent years, the most striking epidemiological finding in relation to ulcerative colitis is the recognition that it is predominantly a disease of non-smokers ${ }^{1}$ and risk of its development in ex-smokers is between four and five times the expected risk in the general population. ${ }^{2}$ Elucidation of the mechanisms responsible for these observations may not establish nicotine as a 'treatment' but should open the way to new treatments that operate through similar mechanisms.

This study was approved by the Animal Experimental Committee of the Erasmus University of Rotterdam. We are grateful to Mrs J de Kam in the Laboratory of Experimental Surgery for implanta-
tion of the mini-pumps, to Dr R G Newcombe of the Department tion of the mini-pumps, to Dr R G Newcombe of the Department of Medical Computing and Statistics, and to the Department of Medical Ill

1 Harries AD, Baird A, Rhodes J. Non-smoking: a feature of ulcerative colitis. BMF 1982; 285: 706 .

2 Motley RJ, Rhodes J, Kay S, Morris TJ. Late presentation of ulcerative colitis in ex-smokers. Int $\mathcal{F}$ Colorectal Dis 1988; 3 :

3 De Castella $\mathrm{H}$. Non-smoking: a feature of ulcerative colitis [letter]. $B M \mathcal{F}$ 1982; 184: 1706

4 Jick H, Walter RM. Cigarette smoking and ulcerative colitis [Letter]. New Engl f Med 1983; 308: 1467-7.

5 Rudra T, Motley RJ, Rhodes J. Does smoking improve colitis Scand $\mathcal{F}$ Gastroenterol 1989; 24 (suppl 170): 61-3.

6 Srivastava ED, Russell MAH, Feyerabend C, Williams GT, Masterson JG, Rhodes J. Transdermal nicotine in active ulcerative colitis. European fournal of Gastroenterology and Hepatology 1991; 3: 815-18.

7 Allen A, Hoskins I. Colonic mucus in health and disease. In: Kirsner IB, Shorter RG eds. Disease of the colon and rectum. Kirsner IB, Shorter RG eds. Disease of the colon

8 Sakata T, Englehart WV. Luminal mucin in the large intestine of mice, rats and guinea pigs. Cell Tissue Research 1981; 219 . of mice,

9 Rozee KRD, Cooper D, Lam K, Casterton JW. Microbial flora of the mouse ileum layer and epithelial surface. Appl Environ Microbiol 1982; 4: 1451-63.

10 Hutton DA, Pearson JP, Allen A, Foster SNE. Mucolysis of the colonic mucus barrier by faecal proteinases: inhibition by interacting polyacrylate. Clin Sci 1990; 78: 265-71.
11 Rhodes JM. Colonic mucus and mucosal glycorptoteins: the key to colitis and cancer? Gut 1989; 30: 1660-6.

12 Jentjens T, Smits HL, Strous GJ. 16,16-Dimethyl prostaglandin E2 stimulates galactose and glucosamine but not serine incorporation in rat gastric mucous cells. Gastroenterology 1984; 87: 409-16.

13 Feyerabend C, Russell MAH. A rapid gas liquid chromatographic method for the determination of cotinine and nicotine in biological fluids. $\mathcal{F}$ Pharm Pharmacol 1990; 42: nicotine 2 .

14 Kerss S, Allen A, Garner A. A simple method for measuring thickness of the mucus gel layer adherent to rat, frog and human gastric mucosa: influence of feed prostaglandin $\mathrm{N}$ acetylcysteine and other agents. Clin Sci 1982; 63: 187-95.

15 Rhodes M, Allen A, Dowling RH, Murphy G, Lennard TWJ. Aspirin in the prevention of gallstones - inhibition of human gall bladder mucus synthesis in patients undergoing cholecystectomy. Gut 1992; 33: 1113-17.

16 Hunter AC, Allen R, Garner A. Studies of mucus biosynthesis in the gastrointestinal tract. In: Chantler E, Ratcliffe NA, eds. Mucus and related topics. Cambridge: Company of Biologists, 1989: 27-36.

17 Allen A. Gastrointestinal mucus (Handbook of physiology. Vol III). Bethesda, MA: American Physiological Society, 1989: 359-82.

18 Bradford MM. A refined and sensitive method for the quantitation of microgram quantities of protein utilizing the principle of protein-dye binding. Anal Biochem 1976; 72 : 248 .

19 Kissane JM, Robins E. The fluorometic measurement of deoxyribosenucleic acid in animal tissues with special reference to the central nervous system. DNA assay. $\mathcal{F}$ Biol Chem 1958; 233: 184-8.

20 Van der Ham AC, Kort WJ, Beijma AM, Zijlstra FJ, Vermeer MA, Jeekel J. Eicosanoid profile of healing colon anastamosis and peritoneal macrophages in the rat. Gut 1990; 30: 80711.

21 Ziilstra FJ, Wilson JHP. 15-HETE is the main eicosanoid present in mucus of acute ulcerative colitis. Prostaglandin present in mucus of acute ulcerative col
Leukotr Essent Fatty Acids 1991; 43: 55-9.

22 Zijlstra FJ, Van Dijk APM, Wilson JHP, Van Riemsdijk-Van Overbeecke IC, Ouwendijk RJT. 15-HETE is the main Overbeecke IC, Ouwendijk RJT. 15-HETE is the main arachidonic acid metabolite formed

23 Culling CFA, Allison RT, Barr WT. Cellular pathology technique. 4th ed. London: Butterworths, 1985

24 Russell MAH, Jarvis MJ, Feyerabend C, Saloojee Y. Reduction of tar, nicotine and carbon monoxide intake in low tar smokers. f Epidemiol Community Health 1986; 40: 80-5.

25 Cope GF, Heatley RV, Kelleher J. Smoking and colonic mucus in ulcerative colitis. $B M \mathcal{F}$ 1986; 293 : 481 .

26 Corfield AP, Williams AJK, Clamp JR, Wagner SA, Mountford RA. Degradation by bacterial enzymes of colonic mucus from normal subjects and patients with inflammatory bowel disease: the role of salicylic acid metabolism and the bowel disease: the role of salicylic acid metabolism and the detection of a
$1988 ; 74: 71-8$.

27 Samson HJ, Allen A, Pearson JP, Cunliffe WJ, Rhodes M, Rhodes J. Faecal proteinase activity: raised values in patients with ulcerative colitis. Gut 1991; 32: A1235.

28 Motley RJ, Rhodes J, Williams G, Tavares IA, Bennett A. Smoking, eicosanoids and ulcerative colitis. $\mathcal{F}$ Pharm Pharmacol 1990; 42: 288-9.

29 Quimby GF, Bernice CA, Bernstein SH, Eastwood GL. Active smoking depresses prostaglandin synthesis in human gastric mucosa. Ann Intern Med 1986; 104: 616-19.

30 Zijlstra FJ, Vincent JE, Mol WM, Hoogsteden HC, van $\mathrm{Ha}$ PWT, Jongejan RC. Eicosanoid levels in broncho-alveolar lavage fluid of young female smokers and non-smokers. Europ f Clin Invest 1992; 22: 301-6.

31 Rhodes JM, Black RR, Gallimore R, Savage A. Histochemica demonstration of desulphation of normal and IBD rectal demonstration of desulphation of normal and

32 Podolsky DK, Isselbacher KH. Glycoprotein composition of colonic mucosa: specific alterations in ulcerative colitis. Gastroenterology 1984; 87: 991-8.

33 Allen A, Hutton DA, Pearson JP, Sellers LA. The colonic mucus gel barrier: structure, gel formation and degradation. In: Paters TJ, ed. The cell biology of inflammation in the gastrointestinal tract. Hull: Corners Publications, 1990: 113-25.

34 Rhodes JM, Gallimore R, Elias E, Allan RN, Kennedy JF Faecal mucus degrading glycosidases in ulcerative colitis and Crohn's disease. Gut 1985; 26: 761-5.

35 Robert A, Nezamis JE, Lancaster C, Hanchor AJ. Cytoprotection by prostaglandins in rats. Gastroenterology 1979; 77: 433-4.

36 Allan A, Hunter AC, Leonard AJ, Pearson JP, Sellers LA. Peptic activity and the mucus-bicarbonate barrier. In Peptic activity and the mucus-bicarbonate barrier. In: Garner A, Whittle BJ, eds. Advances in drug therapy of

37 Stenson WF. Roleof eicosanoids as mediators of inflammation in inflammatory bowel disease. Scand $\mathcal{F}$ Gastroenterol 1990; 25 (suppl 172): 13-8.

38 Psaila RV, Myers B, Jones IR, Rhodes J. Effect of prostaglandin PGE2 on alcohol induced ulceration in the rat colon. Digestion 1986; 35: 224-8. 